\title{
PENGARUH KOMITE AUDIT, KUALITAS AUDIT, KEPEMILIKAN INSTITUSIONAL, RISIKO PERUSAHAAN DAN RETURN ON ASSETS TERHADAP TAX AVOIDANCE
}

\author{
Fitri Damayanti \\ Tridahus Susanto \\ UIN Syarif Hidayatullah Jakarta \\ fitri.damayanti@uinjkt.ac.id
}

\begin{abstract}
This research aims to analyze and get empirical evidence about the effect of audit committee, audit quality, ownership institutional, corporate risk and return on assets on the tax avoidance. Sample of this research were property and real estate industries which are listed in Indonesian Stock Exchanges during 2010-2013 period. The number of property and real estate industries that were became in this study were 22 companies with 4 years observation that acquired by purposive sampling method. Hypothesis in this research were tested by multiple regression model.The result of this research showed that corporate risk and return on assets influence the tax avoidance. In the other hand, the audit quality, audit committee and ownership institutional didn't influence the tax avoidance.
\end{abstract}

Keywords: Audit committee, audit quality, ownership institutional, corporate risk, return on assets and tax avoidance.

Abstrak. Penelitian ini bertujuan untuk menganalisis dan mendapatkan bukti empiris tentang komite audit, kualitas audit, kepemilikan institusional, risiko perusahaan dan return on assets terhadap tax avoidance. Penelitian ini menggunakan sampel sektor industri property dan real estate yang terdaftar di Bursa Efek Indonesia (BEI) selama periode 2010-2013. Jumlah perusahaan yang dijadikan sampel perusahaan ini adalah 22 perusahaan dengan pengamatan selama 4 tahun dengan menggunakan metode purposive sampling. Pengujian hipotesis penelitian ini menggunakan model regresi berganda. Hasil penelitian menunjukkan bahwa risiko perusahaan dan return on assets berpengaruh terhadap tax avoidance. Sedangkan komite audit, kualitas audit dan kepemilikan institusional tidak berpengaruh terhadap tax avoidance.

Kata Kunci: Komite audit, kualitas audit, kepemilikan institusional, risiko perusahaan, return on assets dan tax avoidance. 


\section{PENDAHULUAN}

Pajak merupakan sumber penerimaan Negara yang paling besar. Pajak yang dipungut oleh Negara difungsikan sebagai sumberdana yang diperuntukan bagi pembiayaan pengeluaran pemerintah dan difungsikan sebagai alat untuk mengatur dan melaksanakan kebijakan di bidang sosial dan ekonomi serta digunakan untuk sebesar-besarnya kemakmuran rakyat. Oleh karena itu wajib pajak badan maupun perseorangan diharapkan dapat patuh dalam melaksanakan kewajiban perpajakaannya secara sukarela dan patuh terhadap peraturan perpajakan. Ketidakpatuhan wajib pajak dapat menimbulkan terganggunya keuangan Negara. Salah satu cara ketidakpatuhan tersebut dilakukan dengan cara tax avoidance, yaitu upaya penghindaran pajak secara legal yang tidak melanggar peraturan perpajakan yang dilakukan wajib pajak dengan cara mengurangi jumlah pajak terutang dengan mencari kelemahan (Hutagoal ,2007 dalam Dewi dan Jati ,2014).

Dalam upaya untuk mengurangi beban pajak pihak manajemen dapat melakukan berbagai macam cara seperti penghindaran pajak (tax avoidance). Penghindaran pajak (tax avoidance) merupakan suatu strategi pajak yang agresif yang dilakukan oleh perusahaan dalam rangka meminimalkan beban pajak, sehingga kegiatan ini memunculkan risiko bagi perusahaan antara lain denda dan buruknya reputasi perusahaan dimata publik (Annisa dan Lulus, 2012). Tax avoidance yang dilakukan tersebut dikatakan tidak bertentangan dengan peraturan perudangundangan perpajakan karena dianggap praktik yang berhubungan dengan tax avoidance ini lebih memanfaatkan celah-celah dalam undang-undang perpajakan tersebut yang akan mempengaruhi penerimaan negara sektor pajak (Mangoting ,1999 dalam Dewi dan Jati , 2014). Akan tetapi praktik tax avoidance tidak selalu dapat dilaksanakan karena wajib pajak tidak selalu menghindari semua unsur atau fakta yang dikenakan dalam perpajakan (Dewi dan Jati ,2014).

Menurut Budiman dan Setiyono (2012), Persoalan penghindaran pajak merupakan persoalan yang rumit dan unik. Di satu sisi diperbolehkan akan tetapi disisi lain penghindaran pajak tidak diinginkan. Di indonesia telah dibuat berbagai aturan guna mencegah adanya penghindaran pajak. Salah satunya adalah terkait transfer pricing, yaitu tentang prinsip kewajaran dan kelaziman dalam transaksi antara wajib pajak dengan pihak yang mempunyai hubungan yang istimewa 
(Perdirjen No. PER-43/PJ/2010, 2010).

Penelitian Desai dan Dhamapala (2007), menjelaskan bahwa dari segi tradisional, mekanisme tax avoidance harus meningkatkan nilai pemegang saham dan dalam sebuah perspektif agency menyatakan bahwa tax avoidance menyediakan prediksi yang berbeda. Secara spesifik corporate governance menjadi determinan yang penting dari penilaian yang dimaksud untuk penghematan pajak. Menurut Sartori (2010), terkait pengaruh strategi perpajakan terhadap corporate governance menjelaskan apabila suatu perusahaan memiliki suatu mekanisme corporate governance yang terstruktur dengan baik maka akan berbanding lurus dengan kepatuhan perusahaan dalam memenuhi kewajiban perpajakannya.

Good corporate governance merupakan tata kelola perusahaan yang menjelaskan hubungan antara berbagai partisipan dalam perusahaan yang menentukan arah kinerja perusahaan (Haruman, 2008 dalam Annisa dan Lulus, 2012). Isu corporate governance mulai berkembang pada tahun 1998, ketika di Indonesia mengalami krisis moneter berkepanjangan. Banyak pihak yang menyatakan pendapatnya bahwa lamanya proses pemulihan krisis di Indonesia disebabkan oleh lemahnya corporate governance yang di terapkan oleh perusahaanperusahaan di Indonesia. Mulai sejak saat itu pihak investor dan pemerintah mulai memberikan perhatian yang serius dalam menjalankan prinsip corporate governance (Annisa dan Lulus ,2012).

Corporate governance merupakan sistem dan struktur yang mengatur hubungan antara pihak manajemen dengan pemilik baik yang memiliki saham mayoritas maupun minoritas di suatu perusahaan. Corporate governance berguna untuk melindungi investor dari adanya perbedaan kepentingan pemegang saham (principle) dengan pihak manajemen (agent). Masalah dalam coroprate governance terjadi karena adanya pemisahan antara kepemilikan dan pengendalian perusahaan. Dewan komisaris yang berperan sebagai agent dalam suatu perusahaan diberi wewenang untuk mengurus jalannya perusahaan dan mengambil keputusan atas nama pemilik, namun agent tersebut memiliki kepentingan yang berbeda dengan pemegang saham.

Komite audit merupakan komite yang beranggotakan sekurang-kurangnya tiga orang. Tugas dan fungsi komite audit adalah mengawasi tata kelola perusahaan 
dan mengawasi audit eksternal atas laporan keuangan perusahaan. Komite audit dibentuk oleh dewan komisaris sehingga komite audit bertanggung jawab kepada dewan komisaris. Komite audit juga digambarkan sebagai mekanisme monitoring yang dapat meningkatkan fungsi audit untuk pelaporan eksternal perusahaan. Para dewan perusahaan sering memberikan tanggung jawab kepada komite audit terhadap kesalahan pelaporan keuangan agar laporan keuangan dapat dipercaya (relevant dan realialible). Oleh karena itu komite audit dapat memonitoring mekanisme yang dapat memperbaiki kualitas informasi bagi pemilik perusahaan atau Shareholders dan manejemen perusahaan, karena kedua belah pihak tersebut memiliki level informasi yang berbeda (Linda, Lilis dan Nuraini ,2011).

Kualitas audit adalah segala kemungkinan yang dapat terjadi saat auditor mengaudit laporan keuangan klien dan menemukan pelanggaran atau kesalahan yang terjadi dan melaporkannya dalam laporan keuangan auditan (Dewi dan Jati ,2014). Dalam melakukan pengauditan hal yang terpenting dalam pelaksanaannya adalah transparansi yang merupakan salah satu unsur dari good corporate governance. Transparansi terhadap pemegang saham dapat dicapai dengan melaporkan hal-hal terkait perpajakan pada pasar modal dan pertemuan para pemegang saham. Peningkatan transparansi terhadap pemegang saham dalam hal pajak semakin dituntut oleh otoritas publik (Sartori , 2010). Karena asumsi adanya implikasi dari perilaku pajak yang agresif, perusahaan mereka mengambil posisi agresif dalam hal pajak dan akan mencegah tindakan tersebut jika mereka tahu sebelumnya.

Laporan keuangan yang diaudit oleh auditor KAP The Big Four menurut beberapa referensi lebih berkualitas sehingga menampilkan nilai perusahaan yang sebenarnya, oleh karena itu diduga perusahaan yang diaudit oleh KAP The Big Four (Price Water House Cooper - PWC, Deloitte Touche Tohmatsu, KPMG, Ernst \& Young - E\&Y) memiliki tingkat kecurangan yang lebih rendah dibandingkan dengan perusahaan yang diaudit KAP Non The Big Four (Annisa dan Lulus ,2012). Menurut Chai dan Liu (2010), jika nominal pajak yang dibayar telalu tinggi biasanya akan memaksa perusahaan untuk melakukan penggelapan pajak, maka semakin berkualitas audit suatu perusahaan, maka perusahaan tersebut 
cenderung tidak melakukan manipulasi laba untuk kepentingan perpajakan.

Kepemilikan institusional merupakan kepemilikan saham yang dimiliki oleh pemerintah, perusahaan asuransi, investor luar negeri atau bank (Dewi dan Jati, 2014). Karena adanya tanggung jawab perusahaan kepada pemegang saham, maka pemilik instusional memiliki insentif untuk memastikan bahwa manajemen perusahaan membuat keputusan yang akan memaksimalkan kesejahteraan pemegang saham. Pada pengungkapan suka rela menemukan bahwa perusahaan dengan kepemilikan institusional yang lebih besar lebih memungkinkan untuk mengeluarkan, meramalkan dan memperkirakan sesuatu lebih spesifik, akurat dan optimis (Khurana ,2009).

Risiko perusahaan merupakan volatilitas earning perusahaan, yang bisa diukur dengan rumus deviasi standar. Dengan demikian dapat dimaknai bahwa risiko perusahaan (corporate risk) merupakan penyimpangan atau deviasi standar dari earning baik penyimpangan itu bersifat kurang dari yang direncanakan (downside risk) atau lebih dari yang direncanakan (upset potensial), semakin besar deviasi standar earning perusahaan mengindikasikan semakin besar pula risiko perusahaan yang ada. Tinggi rendahnya risiko perusahaan ini mengindikasikan karakter eksekutif apakah termasuk risk taker atau risk averse (Paligovora, 2010).

Menurut Coles, Daniel, Naveen D, Naveen dan Lalitha (2004) menyatakan bahwa risiko perusahaan (corporate risk) merupakan cermin dari policy yang diambil oleh pemimpin perusahaan. Policy yang diambil pimpinan perusahaan bisa mengindikasikan apakah mereka memiliki karakter risk taking atau risk averse. Semakin tinggi corporate risk maka eksekutif semakin memiliki karakter risk taker, demikian juga semakin rendah corporate risk maka eksekutif akan memiliki karakter risk averse. Terkait dengan karakter eksekutif, Lewellen (2003) menyebutkan bahwa karakter eksekutif yang risk taker lebih berani membuat keputusan melakukan pembiayaan hutang, mereka memiliki informasi yang lengkap tentang biaya dan manfaat hutang tersebut.

Return on Assets merupakan satu indikator yang mencerminkan performa keuangan perusahaan, semakin tinggi nilai ROA, maka akan semakin bagus performa perusahaan tersebut. ROA berkaitan dengan laba bersih perusahaan dan pengenaan pajak penghasilan untuk wajib pajak (Kurniasih dan Sari, 2013). Kasus-kasus 
yang mengenai penghindaran pajak yang pernah dilakukan oleh perusahaan ternama seperti Apple Inc, Starbuck, kasus-kasus lainnya yang membuat pendapatan negara pada sektor perpajakan berkurang (Merdeka.com).

Tabel 1. Skandal penghindaran pajak

\begin{tabular}{|c|c|c|}
\hline No. & Nama Perusahaan & Tuduhan Kasus Kecurangan \\
\hline 1 & Apple Inc (2012) & $\begin{array}{l}\text { Menyembunyikan uang pendapatan } \\
\text { senilai US\$ } 11 \text { Miliar di negara-negara yang } \\
\text { mendapat keringanan pajak (tax haven) antara } \\
\text { lain Virginia Island, Irlandia dan Luxembroug. } \\
\text { Sehingga pajak yang dibayarkan kecil. }\end{array}$ \\
\hline 2 & Starbuck (2012) & $\begin{array}{l}\text { Membuat laporan keuangan seolah rugi } \\
\text { yaitu dengan cara: Membayar royalti atas desain, } \\
\text { resep dan logo ke cabang di Belanda. Membayar } \\
\text { utang bunga sangat tinggi, dimana utang } \\
\text { tersebut ternyata digunakan untuk ekspansi } \\
\text { kedai kopi di negara lain. Membeli bahan baku } \\
\text { dari cabang di Swiss. Walaupun pengiriman } \\
\text { barang langsung dari negara produsen dan tidak } \\
\text { masuk ke Swiss. }\end{array}$ \\
\hline 3 & $\begin{array}{l}\text { Perusahaan internet } \\
\text { search engine di } \\
\text { Amerika } \\
\text { Serikat (2011) }\end{array}$ & $\begin{array}{l}\text { Perusahaan tersebut membukukan revenue } \\
\text { di Inggris sebesar } 398 \text { juta pounds pada tahun } \\
2011 \text {, tetapi hanya membayar pajak } \\
6 \text { juta pounds. Keuntungan perusahaan cabang } \\
\text { Inggris tersebut ternyata di transfer ke cabang di } \\
\text { Irlandia, Belanda dan Bermuda. Negara bermuda } \\
\text { adalah tax haven country yang tidak memungut } \\
\text { PPh Badan. }\end{array}$ \\
\hline 4 & $\begin{array}{l}\text { Perusahaan Investment } \\
\text { Banking dari Amerika } \\
\text { Serikat (2012) }\end{array}$ & $\begin{array}{l}\text { Agar pembayaran bonus tidak terdeteksi, } \\
\text { karyawan perusahaan investment banking } \\
\text { cabang Ingris diminta mengajukan } \\
\text { permohonan pinjaman lunak ke investasi } \\
\text { banking cabang Amerika Serikat dengan dalih } \\
\text { pinjaman lunak, karyawan investasi banking } \\
\text { cabang Inggris tidak harus membayar pajak } \\
\text { penghasilan. Atas hal tersebut, perusahaan } \\
\text { investment banking cabang Inggris didenda } \\
500 \text { juta pounds (Rp. } 7,5 \text { Triliun). }\end{array}$ \\
\hline
\end{tabular}

Sumber:http://www.merdeka.com/peristiwa/penghindaran-pajak-perusahaan global-di-dunia.html.

Tujuan dalam penelitian ini adalah untuk memberikan bukti empiris mengenai pengaruh komtie audit, kualitas audit, kepemilikan institusional, risiko perusahaan dan Retun on Assets terhadap Tax Avoidance (Penghindaran Pajak) pada semua 
perusahaan sektor industri property dan real estate yang terdaftar di Bursa Efek Indonesia (BEI).

\section{METODOLOGI}

Populasi dalam penelitian ini adalah perusahaan go public property dan real estate yang merupakan emiten Bursa Efek Indonesia (BEI) selama periode 20102013. Teknik pemilihan sampel dalam penelitian ini adalah dengan menggunakan purposive sampling.. Metode ini dipilih peneliti karena dianggap memudahkan peneliti dalam melakukan penelitian ini. Adapun beberapa kriteria sampel penelitian, antara lain: Perusahaan dalam sektor industri property dan real estate yang terdaftar di BEI pada periode 2012-2013 secara berturut-turut. Perusahaan yang menyajikan informasi keuangan lengkap dan laporan tahunan lengkap (annual report) berupa informasi berupa nama CEO atau Direktur utama, komite audit, nama KAP yang mengaudit. Perusahaan yang menggunakan mata uang rupiah, agar kriteria pengukuran mata uangnya sama. Perusahaan dengan nilai laba agar tidak mengakibatkan nilai Cash Effective Tax Rate (CETR) terdistorsi (Zimmerman, 2003 dalam Kurniasih dan Sari, 2013). Data yang digunakan dalam penelitian ini berupa laporan tahunan dan laporan keuangan auditan perusahaan tahun 2010-2013 yang telah dipublikasikan secara lengkap di BEI dan website www.idx.co.id.

\section{Definisi Operasional Variabel}

Variabel dalam penelitian ini adalah variabel dependen adalah tax avoidance. Tax Avoidance (Y) Penghindaran pajak merupakan usaha untuk mengurangi, atau bahkan meniadakan hutang pajak yang harus dibayar perusahaan dengan tidak melanggar undang-undang yang ada (Budiman dan Setiyono, 2012). Menurut Dyreng, Scott, Hanlon, Michelle dan Edward (2010), variabel ini dihitung melalui CASH ETR (Cash Effective Tax Rate) perusahaan yaitu kas yang dikeluarkan untuk biaya pajak dibagi dengan laba sebelum pajak. Semakin besar CASH ETR ini mengindikasikan semakin rendah tingkat penghindaran pajak perusahaan.

Variabel Independen berupa Komite Audit, Kualitas Audit, Kepemilikian Institusional, Risiko Perusahaan dan Return on Assets.

a. Komite Audit (X1)

Komite audit adalah komite yang bertanggung jawab mengawasi audit 
eksternal dan merupakan kontak utama antara auditor dengan perusahaan (Dewi dan Jati, 2014). Menurut Andriyani (2008) dalam Kurniasih dan Sari (2013), komite audit di ukur dengan menggunakan variable dummy yang bernilai 1 jika komite audit berjumlah tiga anggota, dan bernilai 0 jika komite audit kurang dari tiga anggota. Dewan komisaris wajib membentuk komite audit yang beranggotakan sekurang-kurangnya tiga orang anggota diangkat serta diberhentikan serta bertanggung jawab kepada dewan komisaris. Komite audit yang beranggotakan sedikit, cenderung dapat bertindak lebih efisien, namun juga memiliki kelemahan, yakni minimnya pengalaman anggota, sehingga anggota komite audit seharusnya memiliki pemahaman memadai tentang pembuatan laporan keuangan dan pengawas prinsip-prinsip pengawasan internal. Kualifikasi terpenting dari anggota komite audit adalah pada commonsense, kecerdasan dan suatu pandangan yang independen (Pohan, 2008 dalam Annisa dan Lulus, 2012).

b. Kualitas Audit (X2)

Kualitas audit adalah segala kemungkinan yang dapat terjadi saat auditor mengaudit laporan keuangan klien dan menemukan pelanggaran atau kesalahan yang terjadi dan melaporkannya dalam laporan keuangan auditan (Dewi dan Jati, 2014). Transparansi terhadap pemegang saham dapat dicapai dengan melaporkan hal-hal terkait perpajakan pada pasar modal dan pertemuan para pemegang saham. Peningkatan transparansi terhadap pemegang saham dalam hal pajak semakin dituntut oleh otoritas publik (Sartori, 2010). Karena asumsi adanya implikasi dari dari perilaku pajak yang agresif, perusahaan mereka mengambil posisi agresif dalam hal pajak dan akan mencegah tindakan tersebut jika mereka tahun sebelumnya. Oleh Karena itu, kualitas audit diukur dengan menggunakan variable dummy yang bernilai 1 apabila audit laporan keuangan dilakukan oleh Kantor Akuntan Publik (KAP) The Big Four yaitu Price Water House Cooper-PWC, Deloitte Touche Tohmatsu, KPMG, dan Ernst \& Young$E \& Y$, dan bernilai 0 apabila audit laporan keuangan tidak dilakukan oleh Kantor Akuntan Publik (KAP) The Big Four.

c. Kepemilikan Institusional (X3)

Kepemilikan institusional adalah kepemilikan saham yang dimilki oleh pemerintah, perusahaan asuransi, investor luar negeri, atau bank, kecuali 
kepemilikan individual investor (Dewi dan Jati, 2014). Dalam penelitian Shleifer dan Vishney (1986) dalam Annisa dan Lulus (2012) menyatakan bahwa pemilik institusional memainkan peran yang penting dalam memantau, mendisiplinkan, dan mempengaruhi manajer. Mereka berpendapat bahwa seharusnya pemilik institusional berdasarkan besar dan hak suara yang dimiliki, dapat memaksa manajer untuk berfokus pada kinerja ekonomi dan menghindari peluang untuk berperilaku mementingkan diri sendiri. Adanya tanggung jawab perusahaan kepada fidusia, maka pemilik institusional memiliki insentif untuk memastikan bahwa manajemen perusahaan membuat keputusan yang akan memaksimalkan kesejahteraan pemegang saham. Kepemilikan institusional diukur dengan proporsi saham yang dimiliki institusi pada akhir tahun yang dinyatakan dalam presentase.

d. Risiko perusahaan (X4)

Risiko perusahaan mencerminkan penyimpangan atau deviasi standar dari earning baik penyimpangan itu bersifat kurang dari yang direncanakan atau mungkin lebih dari yang direncanakan, semakin besar deviasi earning perusahaan mengidentifikasikan semakin besar pula risiko perusahaan yang ada (Budiman dan Setiyono, 2012). Oleh Paligrova (2010) untuk mengukur risiko perusahaan ini dihitung melalui deviasi standar dari EBITDA (Earning Before Income Tax, Depreciation, Amortization) dibagi dengan total aset perusahaan. Besar kecilnya risiko perusahaan mencerminkan apakah eksekutif perusahaan termasuk dalam kategori risk taking atau risk averse, semakin besar risiko perusahaan menunjukan eksekutif perusahaan tersebut adalah risk taking, sebaliknya semakin kecil risiko perusahaan menunjukan eksekutif perusahaan tersebut adalah risk averse.

e. Return on Assets (X5)

Return on Assets (ROA) merupakan gambaran dari kemampuan manajemen untuk memperoleh keuntungan (laba). Semakin Tinggi ROA, maka semakin tinggi keuntungan perusahaan sehingga semakin baik pengelolaan aktiva perusahaan. Menurut Kurniasih dan Sari (2013), variabel ROA (Return on Assets) diukur dengan membandingkan antara laba bersih dengan total aset perusahaan pada akhir periode, yang digunakan sebagai indikator kemampuan 
perusahaan dalam menghasilkan laba. Menurut Atmaja (2008), Return on Assets (ROA) dapat diukur dengan menggunakan rumus sebagai berikut:

$$
\begin{gathered}
\text { ROA }=\text { Laba Bersih x 100\% } \\
\frac{\text { Total }}{\text { Aset }}
\end{gathered}
$$

Analisis data dilakukan dengan statistik deskriptif, uji asumsi klasik (normalitas, multikolinearitas, dan heteroskedastisitas) dan regresi linier berganda serta pengujian hipotesis (koefisien determinasi, uji $F$ dan uji $t$ ) dengan bantuan perangkat lunak IBM Statistical Package for Social Sciences (SPSS) versi 21.0.

Rumus persamaan regresi yang digunakan adalah sebagai berikut :

$$
\begin{aligned}
& \mathrm{Y}=\beta 0+\beta 1 \mathrm{KMT}+\beta 2 \mathrm{ADT}+\beta 4 \mathrm{INST}+\beta 3 \mathrm{RSK}+\beta 5 \mathrm{ROA}+\varepsilon \\
& \text { Keterangan: } \\
& \text { Y : Tax Avoidance } \\
& \beta \quad \text { : Konstanta } \\
& \beta 1 \beta 2 \beta 3 \quad \text { : Koefisien Regresi } \\
& \text { KMT : Komite Audit } \\
& \text { ADT } \quad \text { : Kualitas Audit } \\
& \text { INST } \quad \text { : Kepemilikan Institusional } \\
& \text { RSK : Risiko Perusahaan } \\
& \text { ROA : Return on Assets } \\
& \varepsilon \quad: \quad \text { Faktor Pengganggu }
\end{aligned}
$$

\section{PEMBAHASAN}

Populasi penelitian ini adalah perusahaan property dan real estate yang terdaftar di Bursa Efek Indonesia (BEI) pada periode 2010-2013. Perusahaan property dan real estate tersebut tidak keluar dari BEI (delisting). Sampel yang digunakan dalam penelitian ini dipilih secara purposive sampling, sehingga sampel dalam penelitian ini merupakan representasi dari populasi sampel yang ada, serta sesuai dengan tujuan penelitian. Berdasarkan kriteria sampel yang berhasil 
diperoleh dalam penelitian ini sebanyak 22 perusahaan sektor property dan real estate yang terdaftar di Bursa Efek Indonesia (BEI) periode 2010-2013.

Statistika deskriptif pada tabel menunjukkan nilai minimum, maksimum, rata-rata dan standar deviasi dari masing-masing variabel penelitian.

Tabel Hasil Uji Statistik Deskriptif

\begin{tabular}{|l|c|c|c|c|c|}
\hline & & & & & Std. \\
\hline Komite Audit & 88 & 0 & 1 & 0,91 & 0,289 \\
\hline Kualitas Audit & 88 & 0 & 1 & 0,31 & 0,464 \\
\hline Kepemilikan & 88 & 0,179 & 0,977 & 0,63070 & 0,203488 \\
\hline Risiko Perusahaan & 88 & 0,003 & 0,095 & 0,04057 & 0,020715 \\
\hline Return on Assets (ROA) & 88 & 0,014 & 0,200 & 0,06620 & 0,033393 \\
\hline Tax Avoidance & 88 & 0,015 & 0,374 & 0,16533 & 0,062485 \\
\hline
\end{tabular}

Sumber: Data sekunder diolah

Mengenai uji asumsi klasik, uji normalitas dilakukan dengan menggunakan Kolmogrov-Smirnov $Z$ (I-Sample K-S). hasil uji Kolomogrov-Smirnov (K-S) menunjukkan bahwa data terdistribusi secara normal. Hal ini dapat terlihat dari tingkat signifikansi sebesar 0,055 dan nilainya diatas $\alpha=0,05$. Pengujian tersebut menunjukkan bahwa data terdistribusi normal. Uji multikorlinearitas yang digunakan adalah dengan melihat VIF (variance-inflating factor) dan Tolerance (1/VIF). Jika VIF < 10 dan Tolerance > 0,1 maka tingkat kolineritas dapat ditoleransi. hasil uji multikolonieritas dengan nilai VIF berkisar antara 1,144 sampai dengan 3,291. Sedangkan nilai tolerance berkisar antara 0,304 sampai dengan 0,874. Maka dari hasil tersebut dapat disimpulkan bahwa model penelitian ini tidak terjadi multikolonieritas. Hasil uji heteroskedastisitas menggunakan uji scatterplot dan uji glejser. Dari hasil uji scatterplot tersebut terlihat bahwa titik-titik menyebar secara acak pada posisi diatas maupun dibawah angka nol pada sumbu Y. Jadi dapat disimpulkan model regresi tidak mengandung adanya heteroskedastisitas. Uji Autokorelasi yang digunakan adalah dengan melihat nilai Durbin- Watson. Dari hasil pengujian autokolerasi menggunakan Durbin Watson statistik, maka didapatkan hasil nilai DW berada diantara dU dan 4-dU yaitu diantara 1,774 dan 2.475 sehingga dapat disimpulkan bahwa semua model regresi terlepas dari masalah autokolerasi. 
Hasil uji koefisien determinasi (Adjusted $\mathrm{R}^{2}$ ) dapat dilihat pada Tabel berikut:

Tabel Hasil Pengujian Koefisien Determinasi

\begin{tabular}{|c|c|}
\hline Model & Adjusted $R$ Square \\
\hline 1 & 0,345 \\
\hline
\end{tabular}

Sumber: Data sekunder diolah

Pada tabel memperlihatkan Adjusted $R$ Square adalah sebesar 0,345. Hal ini berarti sebesar 34,5\% variabel tax avoidance dapat dijelaskan oleh variabel komite audit, kualitas audit, kepemilikan institusional, risiko perusahaan dan return on assets. Sedangkan sisanya yaitu sebesar $(100 \%-34,5 \%=65,5 \%)$ dijelaskan oleh faktor-faktor lain yang tidak diketahui dan tidak termasuk dalam analisa regresi pada penelitian ini. Variabel-variabel lain yang mempengaruhi tax avoidance menurut Kurniasih dan Sari (2013) yaitu Leverage, dan kompensasi rugi fiskal.

\section{Tabel Hasil Uji Statistik F}

\begin{tabular}{|c|c|c|c|}
\hline Model & Nilai F & Sig & Kesimpulan \\
\hline Regression & 10.164 & 0,000 & Fit \\
\hline
\end{tabular}

Sumber: Data sekunder diolah

Berdasarkan tabeL menunjukkan bahwa hasil uji statistik F memiliki nilai probability sebesar 0,000 lebih kecil dari 0,05. Maka dapat disimpulkan bahwa secara simultan seluruh variabel komite audit, kualitas audit, kepemilikan institusional, risiko perusahaan dan return on assets secara bersama-sama mempengaruhi variabel dependennya yaitu tax avoidance.

Uji statistik t digunakan untuk mengetahui ada tidaknya pengaruh masingmasing variabel independen secara individual terhadap variabel dependen. Tabel 4.10 berikut ini menyajikan hasil uji statistik t dalam penelitian ini, yaitu:

\section{Tabel Hasil Uji Statistik t}

\begin{tabular}{|l|c|c|c|}
\hline & B & Sig & Kesimpulan \\
\hline (Constant) & 0,216 & 0,000 & - \\
\hline KMT & $-0,011$ & 0,574 & Tidak Berpengaruh \\
\hline ADT & 0,012 & 0,325 & Tidak Berpengaruh \\
\hline INST & 0,010 & 0,716 & Tidak Berpengaruh \\
\hline RSK & 1,715 & $0,000^{*}$ & Berpengaruh \\
\hline ROA & $-1,812$ & $0,000^{*}$ & Berpengaruh \\
\hline
\end{tabular}

*Signifikansi pada $\alpha 5 \%$

Sumber: Data sekunder diolah 
Berdasarkan table hasil uji hipotesis Ha1 menunjukkan bahwa variabel komite audit tidak berpengaruh signifikan terhadap tax avoidance. Dapat dilihat dalam tabel 4.11, menunjukkan nilai koefisien beta yang dihasilkan sebesar $-0,011$, dengan tingkat signifikan sebesar 0,574 lebih besar daripada $\alpha=0,05$. Dengan demikian hipotesis Ha1 ditolak sehigga dapat dikatakan bahwa komite audit tidak berpengaruh signifikan terhadap tax avoidance. Menurut BEI dan Bapepam-LK, setiap perusahaan yang terdaftar di BEI wajib memiliki komite audit, yang anggotanya terdiri dari satu orang komisaris independen sebagai ketua dan minimal 2 orang pihak eksternal perusahaan yang independen sebagai anggota. Dewan komisaris wajib membentuk komite audit sekurang-kurangnya tiga orang yang di angkat dan diberhentikan serta bertanggng jawab terhadap dewan komisaris. Komite audit yang beranggotakan sedikit, cenderung, dapat bertindak lebih efisien, namun juga memiliki kelemahan, yakni minimnya pengalaman anggota. Hasil penelitian ini mendukung penelitian yang dilakukan oleh Kurniasih dan Sari (2013) dan Fadhilah (2014) yang menyatakan bahwa komite audit tidak berpengaruh signifikan terhadap tax avoidance. Akan tetapi hasil ini berlawanan dengan logika penyusunan hipotesis. Hasil ini tidak mendukung hasil penelitian yang dilakukan oleh Annisa dan Lulus (2012), dan Dewi dan Jati (2014).

Berdasarkan hasil tabel hipotesis Ha2 menunjukan bahwa variable kualitas audit tidak berpengaruh signifikan terhadap tax avoidance. Dapat dilihat nilai koefisien beta sebesar 0,012, dengan tingkat signifikansi sebesar sebesar 0,325 lebih besar dari $\alpha=0,05$. Dengan demikian hipotesis Ha2 ditolak sehingga dapat dikatakan bahwa kualitas audit tidak berpengaruh signifikan terhadap tax avoidance. Hasil ini mendukung penelitian yang telah dilakukan oleh Kurniasih dan Sari (2013) dan Fadhilah (2014). Tetapi tidak mendukung penelitian Annisa dan Lulus (2012), dan Dewi dan Jati (2014). Perusahaan yang diaudit oleh KAP the big four memang akan lebih cenderung dipercayai oleh fiskus karena KAP tersebut memiliki reputasi yang baik, memiliki integritas yang tinggi, namun jika perusahaan bisa memberikan keuntungan dan kesejahteraan yang lebih baik terhadap KAP yang mempunyai reputasi yang baik, bisa saja KAP tersebut melakukan kecurangan untuk memaksimalkan kesejahteraan KAP, seperti halnya kasus Enron tahun 2004 (Fadhilah, 2014). 
Berdasarkan hasil tabel hipotesis Ha3 menunjukan bahwa variabel kepemilikan institusional tidak berpengaruh signifikan terhadap tax avoidance. Dapat dilihat dari tabel 4.11 menunjukkan nilai koefisien beta sebesar 0,010, dengan tingkat signifikansi sebesar sebesar 0,716 lebih besar dari $\alpha=0,05$. Dengan demikian hipotesis Ha4 ditolak sehingga dapat dikatakan bahwa kepemilikan institusional tidak berpengaruh signifikan terhadap tax avoidance. Hasil ini mendukung penelitian yang telah dilakukan oleh Dewi dan Jati (2014) dan Fadhilah (2014). Kepemilikan institusional merupakan kepemilikan saham yang dimiliki oleh institusi seperti pemerintah, perusahaan asuransi, investor luar negeri, atau bank kecuali kepemilikan individual. Pemilik institusional ikut serta dalam pengawasan dan pengelolaan perusahaan namun pemilik institusional mempercayakan pengawasan dan pengelolaan tersebut kepada dewan komisaris karena itu merupakan tugas dewan komisaris yang mewakili pemilik institusional. Akan tetapi ada atau tidaknya kepemilikan institusional dalam sebuah perusahaan tetap saja akan terjadi tax avoidance (penghindaran pajak).

Berdasarkan hasil table hipotesis Ha4 menunjukan bahwa variabel risiko perusahaan berpengaruh signifikan terhadap tax avoidance. Dapat dilihat dari tabel 4.11 menunjukkan nilai koefisien beta sebesar 1,715, dengan tingkat signifikansi sebesar sebesar 0,000 lebih kecil dari $\alpha=0,05$. Dengan demikian hipotesis Ha4 diterima sehingga dapat dikatakan bahwa risiko perusahaan berpengaruh terhadap tax avoidance. Hasil ini mendukung penelitian yang telah dilakukan oleh Budiman dan Setiyono (2012), dan Dewi dan Jati (2014). Naik-turunnya risiko perusahaan mencerminkan kecenderungan dari karakter eksekutif. Tingkat risiko perusahaan yang lebih tinggi mengindikasikan karakter eksekutif lebih memiliki sifat risk taker dibandingkan dengan tingkat risiko perusahaan yang lebih rendah mengindikasikan karakter eksekutif lebih memiliki sifat risk averse (Budiman dan Setiyono, 2012).

Berdasarkan hasil table hipotesis Ha5 menunjukan bahwa variabel return on assets berpengaruh signifikan terhadap tax avoidance. Dapat dilihat dari tabel menunjukkan nilai koefisien beta sebesar-1,812 dengan tingkat signifikansi sebesar sebesar 0,000 lebih kecil dari $\alpha=0,05$. Dengan demikian hipotesis Ha5 diterima sehingga dapat dikatakan bahwa return on assets berpengaruh signifikan terhadap 
tax avoidance. Hasil ini mendukung penelitian yang telah dilakukan oleh Kurniasih dan Sari (2013). Return on assets adalah salah satu indikator bagi perusahaan dalam pencapaian laba perusahaan. Dimana laba merupakan faktor terpenting dalam penentuan besaran pembayaran tarif pajak efektif. Maka semakin tinggi nilai dari laba bersih perusahaan dan semakin tinggi profitabilitasnya sehingga perusahaan yang memiliki profitabilitas tinggi memiliki kesempatan untuk memposisikan diri dalam tax palnning yang mengurangi jumlah beban kewajiban perpajakan (Chen, et al, 2010).

\section{KESIMPULAN}

Berdasarkan data yang diperoleh dan hasil pengujian yang telah dilakukan dengan menggunakan model regresi berganda, maka dapat disimpulkan bahwa Komite audit tidak berpengaruh terhadap tax avoidance. Hasil ini tidak mendukung hasil penelitian yang dilakukan oleh Annisa dan Lulus (2012), dan Dewi dan Jati (2014). Hasil penelitian tersebut berlawanan karena jumlah komite audit yang berada di dalam perusahaan tidak memberikan jaminan perusahaan akan melakukan tindakan tax avoidance dan jumlah komite audit tidak memberikan jaminan dapat melakukan intervensi dalam peran penentuan kebijakan besaran tarif pajak dalam perusahaan. Kualitas audit tidak berpengaruh terhadap tax avoidance. Hasil ini mendukung penelitian yang telah dilakukan oleh Kurniasih dan Sari (2013) dan Fadhilah (2014). Hasil Penelitian tersebut berlawanan karena KAP The Big Four memiliki banyak pengetahuan tentang cara mendeteksi dan memanipulasi laporan keuangan yang mungkin dilakukan oleh perusahaan sehingga tidak menjamin KAP yang memiliki reputasi yang baik tidak akan melakukan kecurangan penghindaran pajak. Kepemilikan institusional tidak berpengaruh terhadap tax avoidance. Hasil ini mendukung penelitian yang telah dilakukan oleh Dewi dan Jati (2014) dan Fadhilah (2014). Hasil penelitian tersebut berlawanan karena pemilik institusional kurang peduli dengan citra perusahaan asalkan perusahaan tersebut bisa memaksimalkan kesejahteraan pemilik institusional walaupun adanya perilaku manajemen dalam mengambil suatu keputusan terutama dalam hal pajak yaitu dalam tindakan tax avoidance. Risiko perusahaan berpengaruh terhadap tax avoidance. Hasil ini mendukung penelitian yang telah dilakukan oleh Budiman dan Setiyono (2012), dan Dewi dan Jati (2014). Return on assets berpengaruh terhadap tax avoidance. Hasil ini mendukung penelitian Kurniasih dan Sari (2013) 


\section{REFERENSI}

Adi, Anindyarta Wardhana dan Nur Cahyonowati. 2013 "Pengaruh Karakteristik Perusahaan terhadap Tingkat Pengungkapan Risiko". Diponegoro Journal of Accounting, Vol. 2, No. 3, Halaman 1-14.

Amstrong, Christopher. S., Jenniver L. Blouin, Alan D. Jagolinzer dan David F.

Larcker. 2013." Corporate Governance, Incentives and Tax Avoidance”. Rock Center for Corporate Governance Working Paper Series no. 136.

Anggraheni, Niken Susanti. 2010. Analisis Pengaruh Mekanisme Corporate Governance terhadapNilai Perusahaan dengan Kualitas Laba sebagai Variabel Intervening. Simposium Nasional Keuangan I.

Annisa, Nuralifmida Ayu dan Lulus Kurniasih. 2012."Pengaruh Corporate Governance terhadap Tax Avoidance". Jurnal Akuntansi dan Auditing, Vol. 8, No. 2, Mei 2012, hal 95-189.

Anyta, dan M. Siti. 2012. "Voluntary Corporate Governance Disclosure (VCGR) Versi Investor dan Determinasi VCGR di Indonesia. Jurnal Riset Akuntansi Keuangan.

Atmaja, Lukas Setia. 2008. "Teori dan Praktik Manajemen keuangan". Jakarta: Penerbit Andi.

Boediono, Gideon Sb. 2005. "Kualitas Laba: Studi Pengaruh Mekanisme Corporate Governance dan Dampak Manajemen Laba dengan Menggunakan Analisis Jalur". Simposium Nasional Akuntansi VII. Bali.

Budiman, Judi dan Setiyono. 2012. "Pengaruh Karakter Eksekutif terhadap Penghindaran Pajak (Tax Avoidance)". Thesis Universitas Gajah Mada.

Chai, H, dan Liu, Q. 2010.“Competition and Corporate Tax Avoidance: Evidence from Chinese Industrial Firms".

Chen, K. P, dan Chu, C. Y. C. 2010. "Internal Control vs External Manipulation: A Model of Corporate Income Tax Evasion". Rand Journal of Economics. 2010.

Chen, S., Chen, X., Cheng, Q., Shevlin, T. 2010. “Are Family Firms More Tax Aggressive Than Non-Family Firms?". Journal of Financial Economics. 95, 41-61.

Coles, Jeffrey L., Daniel, Naveen D., Naveen, Lalitha.2004. “Managerial Incentive And Risk Taking" The Accounting Review. 
Desai, M.A., Dharmapala, D. 2007. “Corporate Tax Avoidance and High- Powered Incentives". Journal of Financial Economics, 79. 145-179.

Desai, Mihir A. and Dhammika Dharmapala. 2008. "Corporate Tax Avoidance and Firm Value". The Review of Economics and Statistics.

Desai, M. A. dan D. Dharmapala. 2006. “Earnings Management and Corporate Tax Shelters". Working Paper.

Dewi, Ni Nyoman Kristiana dan I Ketut Jati. 2014. "Pengaruh Karakter Ekdekutif, Karakteristik Perusahaan, dan Dimensi Tata Kelola Perusahaan yang Baik Pada Tax Avoidance di Bursa Efek Indonesia". ISSN: 2302-8556. E-Jurnal Akuntansi Universitas Udayana 6.2 (2014):249-260.

Diyanti, Ferry. 2010.“Mekanisme Good Corporate Governance, Karakteristik Perusahaan dan Mandatory Disclosure: Studi Empiris pada Perusahaan Manufaktur yang Terdaftar di BEI". Publikasi Ilmiah Program Magister Sains Akuntansi Fakultas Ekonomi Unversitas Brawijaya.

Dyreng, Scott D., Michelle Hanlon, Edward L. Maydew. 2010. "The Effect of Executives on Corporate Tax Avoidance". The Accounting Review, Vol. 85, Juni 2010, pp 1163-1189.

Fadhilah, Rahmi. 2014. "Pengaruh Corporate Governance terhadap Tax Avoidance". Artikel Universitas Negeri Padang.

Ferrantino, Liu, dan Wang. 2008."Avoidance Behaviors of Exporters and Importers: Evidence From the U.S.-China Trade Data Discrepancy". Office of Economic Working Paper..

Forum for Corporate Governance in Indonesia (FCGI).2003. Corporate Governance: "Tantangan dan Kesempatan bagi Komunitas Bisnis Indonesia". Jakarta.

Freedman, Loomer,Vella. 2009. “Corporate Tax Risk and Tax Avoidance: NewApproaches". Legal Reserch Paper Series No.13/2009.

Frey, B. S and Torgler, B. 2007. "Tax Morale and Conditional Cooperation". Journal of Comparative Economics, Vol. 35, No. 1, pp 136-159

Friese, A., S. Link, dan S. Mayer. 2006."Taxation and Corporate Governance". Working Paper 
Gaertner, F. B. 2009. “CEO After-tax Compensation Incentives and Corporate Tax Avoidance".

Ghozali, Imam. 2011. "Aplikasi Analisis Multivariate dengan Program IBM SPSS 19”, Edisi Kelima Cetakan Kelima, Badan Penerbit Universitas Diponegoro, Semarang.

Gravelle, Jane G. 2009." Tax Havens: International Tax Avoidance and Evasion". National Tax Journal, Vol. LXII, No. 4, pp 727-753.

Hanlon, Michelle and Shane Heitzman. 2010. "A Review of Tax Research". Journal of Accounting and Economics, Vol 50, pp 127-178.

Hanum, Rodhiana dan Zulaikha Hashemi. 2013. " Pengaruh Karakteristik Corporate Governance terhadap Efective Tax Rate". Diponegoro Journal of Accounting, Vol 2, No.2.

Haryati, Rima dan Shiddiq Nur Rahardjo. 2013. "Pengaruh Corporate Sosial Responsibility, Kinerja Lingkungan, dan Struktur Corporate Governance terhadap Kinerja Keuangan Perusahaan yang Terdaftar di Bursa Efek Indonesia". Diponegoro Journal of Accounting.

Hogan, Brian. 2010."The Association Between Changes in Auditor Provided Tax Service and Corporate Tax Avoidance".

Hormati, Asrudin. 2009. "Karakteristik Perusahaan terhadap Kualitas Implementasi Corporate Governance". Jurnal Keuangan dan Perbankan, Vol. 13, No. 2, Mei 2009, hal 288-298.

Khurana, I, K dan W, J, Moser. 2009."Institutional Ownership and Tax Aggressiveness. www.ssrn.com.

Kholbadlov, Utkir. 2012."The Relationship of Corporate Tax Avoidance, Cost of Debt and Institutional Ownnership: Evidence from Malaysia". Atlantic Review of Economics

Kurniasih, Tommy dan Maria M. Ratna Sari. 2013."Pengaruh Return On Assets, Leverage, Corporate Governance, Ukuran Perusahaan dan Kompensasi Rugi Fiskal Pada Tax Avoidance". Buletin Studi Ekonomi Vol 18, No.1 Februari.

Laraswita dan Indrayani. 2010. "Pengaruh Karakteristik Perusahaan terhadap Kelengkapan Pengungkapan dalam Laporan Tahunan Sektor Properti dan Real Estate yang Terdaftar di BEI". www.gunadarma.ac.id. 
Lewellen, Katharina. 2003. "Financing Decisions When Managers Are Risk Averse". Working Paper, Mit Sloan School of Management.

Linda,. Maryasih, Lilis dan Nuraini. 2011. "Komite Audit dan Kinerja Perusahaan: Agency Theory atau Stewerdship Theory?". Simposium Nasional Akuntansi XIV. Aceh.

Low, Angie. 2006. " Managerial Risk-Taking Behavior and Equity-Based Compensation". Fisher College of Business Working Paper September 2006, 03-003.

Mahmoud, Abdussalam Abu Tapanjeh. 2006. “Good Corporate Governance Mechanism and Firms' Operating and Financial Performace: Insight From The Perspective of Jordanian Industrial Companies. J. King Saud Univ., Vol 19. Riyadh.

Meizaroh dan Jurica Lucyanda. 2012."Pengaruh Corporate Governance, Kinerja perusahaan dan Umur Perusahaan terhadap Pengungkapan Model Intelektual". Media Riset Akuntansi.

Michelon, Giovanna dan Antonio Parbonetti. 2010. "The Effect of Corporate Governance on Sustainability Disclosure". Springer Science \& Business Media 14 September.

Moeljadi. 2006. “Manajemen Keuangan Pendekatan Kuantitatif dan Kualitatif. Jilid 1". Malang: Bayumedia Publishing.

Pohan, H, T. 2008. "Pengaruh Good Corporate Governance, Rasio Tobin's q, Perata Laba terhadap Penghindaran Pajak Pada Perusahaan Publik.

Poligovora, Teodora. "Corporate Risk Taking and Ownership Structure". Bank of Canada Working Paper. 2010.

Sari, Dewi Kartika dan Dwi Martani. 2010. “Karakteristik Kepemilikan Perusahaan, Corporate Governance dan Tindakan Pajak Agresif". Simposium Nasional Akuntansi XIII. Purwokerto.

Sartori, Nicola.2010. "Effect of Strategic Tax Behaviors on Corporate Governance. wWW.SSrn.com.

Suartana, I, W.2007. “Upaya Meningkatkan Kualitas Pertimbangan Audit Melalui Self Review Kasus Going Concern perusahaan". Simposium Nasional Akuntansi X. Makasar. 
Suryana, Anandita Budi. 2014. "Penghindaran Pajak Perusahaan Global di Dunia". Diakses melalui http://www.merdeka.com/peristiwa/penghindaranpajak- perusahaan-global-di-dunia.html, pada tanggal 5 Maret

Suyanti, Anggraheni Niken., Rahmawati dan Y. Anni Aryani. 2010. "Pengaruh Mekanisme Corporate Governance terhadap Nilai Perusahaan dengan Kualitas Laba sebagai Variabel Intervening Pada Perusahaan Manufaktur yang Terdaftar di Bursa Efek Indonesia Periode 2004-2007". Jurnal Ekonomi dan Bisnis.

Trinanda, Didin Mukodim.2010. "Effect Of Application Of On The Financial Performance of Banking Sector Companies". www.gunadarma.ac.id.

Xynas, Lidia.2011. "Tax Planning, Avoidance and Evasion in Australia 1970-2010: The Regulatory Responses and Taxpayer Compliance". Revenue Law Journal, Vol.20, No. 1. 